\title{
非地形写真測量のキャリブレーション法
}

\section{A Calibration Method in Non-topographic Photogrammetry}

\author{
服部進* \\ Susumu Hattori
}

\begin{abstract}
In non-topographic photogrammetry using analytical plotters, it is not always the best choise to calibrate cameras in a usual way, in which the projective relation from photographic coordinates to object space coordinates is determined by a collinearity equation with unknown interior and exterior orientation parameters. For in analytical plotters any projective relations are reproduced by computation without a geometrical meaning. Especially in the case of non-metric cameras with unknown and unstable interior orientation like amateur ones, the relation can be determined more favorably by the direct linear transformation (the projective transformation). This method was developed by Abdel-Aziz and karara and now called the DLT method, which is featured by needlessness of fiducial marks. Further the non-topographic calibration problem of cameras with stable or known interior orientation was solved by H. Bopp and H. Krauss. This article explaines these methods plainly, starting from the basic way of thinking for readers who are going to develop computer programs for calibration and plotting in non-topographic photogrammetry.
\end{abstract}

概 要：解析図化機が普及した現在では，非地形写真測量に非測定用力メラが容易に利用できるようになっている。 しかし解析図化機によるキャリブレーションでは, 従来のように内部，外部の標定要素を経由して写真座標系と対象空間 座標系を対応つけるのは必ずしも得策でない。とくにアマチュアカメラのように内部標定要素が未知でまた不安定な場合 には，一般線型変換式（射影変換式）で直接対応関係を決定するのが適している。この方法はDLT 法 (Direct Linear Transformation）法と呼ばれ Abdel-Azizと Kararaにより開発された。また内部標定要素が未知であるが安定したカメ ラのキャリブレーションについては, H. Boppと H. Kraussによって解法が示された。この解説は解析図化機による非地 形写真測量のプログラミングを行ってみようとする人のために上記の手法を基礎の考え方から示したものである。

\section{1.はじめに}

解析困化機が急速に普及してきたため, 測定用カメ ラ (metric camera) 以外のカメラでもキャリブレー ションさえすれば四化に使用できるようになった。と くに近接写真測量を中心とする非地形写真測量では, 焦点を固定していない非測定用カメラ（non-metric camera）を使用せざるを得ないことが多い。いずれの 場合でも，解析図化機を使うときには，従来の手法で 標定し内部外部の標定要素を決定するのは必ずしも上 策ではない。解析図化機はすべての投影関係を計算機 の演算で再現するから, カメラの回転角や画面距離の ような物理量は意味を持たないからである。

非測定用カメラのキャリブレーション法として，す

* 東京大学生産技術研究所

「写真測量とリモートセンシング」vol. 25, No. 4, 1986
でにAbdel-Azis と Karara ${ }^{1), 2)} よ り$ DLT (Direct Liner Transformation）法が開発され実用化されてい るが国内ではあまり知られていない。DLT 法は対象空 間座標系と写真座標系を射影変換式 (一般線型変換式 と呼んでいる）で直接結びつけるものであり，指標， 画面距離を不要とする利点を持っている。

一方測定用カメラについても同様の方法は使用でき るが, 内部標定要素が既知であるから変換係数の間に 拘束を付けないと厳密解は得られない。これについて は H. Boppと H. Krauss ${ }^{3)} よ る$ 簡潔な論文がある。 なお上記の 2 つは単写真ごとにキャリブレーション を実行するが, 複数の写真群を一度にキャリブレー ションする三角測量 (triangulation) 当当然考之られ る。この場合変換係数に回転や平行移動などの個別的 意味がないから，キャリブレーション法としては相互 標定を経由しないバンドル調整によることになる4)。

この解説記事は一般線型変換式によるキャリブレ一 ション法を基礎から説明し, 従来のように一旦内部外 
部の標定要素を経由して変換式を求めるのでなく, 直 接に変換係数を決定する方法を示すものである。ここ に解説する手続きは恐らく多くがすでに市販の解析困 化機に供与されているプログラムに含まれていること が予想される。しかしそれらの大多数はブラックボッ クスになっていて利用者には公開されていない。この 解説は自らプログラムを開発しようとする人の参考に なることを期待している。ページ数の制約からここで は単写真ごとにキャリブレーションする方法のみ示し た。(とくに非測定用カメラの)バンドル調整について は次の機会に紹介する。

なお解説の内容は日本測量協会主催昭和六十一年度 専門技術講習会（写真測量 $\mathrm{A}$ 課程）で著者が行った講 義をもとにしていて，参考文献1),2),3)を易しく書き直し たものである。

\section{2. キャリブレーションの基本式}

\section{1 一般線型変換}

写真座標と対象空間座標との関係が射影変換（一般 線型変換）で近似されることは周知のことである。一 般線型変換を考えるときには，考えている空間より 1 つ次元の高い空間での対応関係を考えるのが便利であ る。通常は 3 次元の対象空間座標系 $X Y Z$ から 2 次元 の写真座標系 $x y$ の変換であるから, その基本式は

$$
\begin{aligned}
& x=\frac{L_{1} X+L_{2} Y+L_{3} Z+L_{4}}{L_{9} X+L_{10} Y+L_{11} Z+1} \\
& y=\frac{L_{5} X+L_{6} Y+L_{7} Z+L_{8}}{L_{9} X+L_{10} Y+L_{11} Z+1}
\end{aligned}
$$

で与えられる。なお 2 次元平面と写真との対応関係の 問題についてはこの解説では省略する。同次座標系

$$
x=\frac{u}{t}, y=\frac{v}{t} ; X=\frac{U}{T}, \quad Y=\frac{V}{T}, Z=\frac{W}{T}
$$

を導入すれば式(1)は

$$
\left[\begin{array}{l}
u \\
v \\
t
\end{array}\right]=\left[\begin{array}{llll}
L_{1} & L_{2} & L_{3} & L_{4} \\
L_{5} & L_{6} & L_{7} & L_{8} \\
L_{9} & L_{10} & L_{11} & 1
\end{array}\right]\left[\begin{array}{l}
U \\
V \\
W \\
T
\end{array}\right]=L\left[\begin{array}{c}
U \\
V \\
W \\
T
\end{array}\right]
$$

と同值である。式(1)，(2)は適当に同意義で用いること にする。上式で $L の （ 3 ， 4)$ 要素は 0 になることは なく，また比のみが重要であるので 1 においている。 式(1)，(2)は11ケの変換係数を含んでいる。これらが全 て独立であるとすれば， 3 次元的に配置された 6 点以
上の基準点に対して最小 2 乗法で未知パラメー夕を決 定できる。DLT 法はその考え方に立っている。一方， 測定用カメラや, キャリブレーションされてはいない がレンズ歪, フィルム歪のない理想的なカメラ（これ を「完全カメラ」と呼ぶことにしよう）では末知の変 換係数は全部が独立でなく従属関係を持つ。したがっ て正しい解を導くには, 変換係数間にどのような関係 があるかを明らかにして，それらの関係を満足するよ うに変換係数の值を決定する必要がある。

まず完全カメラの場合およびそうでない場合の変換 係数間の従属性を調べてみよう。

\section{2 变換係数の従属性と独立性}

レンズ歪, フィルム歪のない完全カメラはピンホー ルカメラのモデルである。この場合完全カメラの式(1) の11個の変換係数のうち独立なものは 9 個である。そ れは通常の共線条件式

$$
\begin{aligned}
& \frac{x-x_{p}}{c} \\
& =\frac{m_{11}\left(X-X_{0}\right)+m_{12}\left(Y-Y_{0}\right)+m_{13}\left(Z-Z_{0}\right)}{m_{31}\left(X-X_{0}\right)+m_{32}\left(Y-Y_{0}\right)+m_{33}\left(Z-Z_{0}\right)} \\
& \frac{y-y_{p}}{c} \\
& \quad=\frac{m_{21}\left(X-X_{0}\right)+m_{22}\left(Y-Y_{0}\right)+m_{23}\left(Z-Z_{0}\right)}{m_{31}\left(X-X_{0}\right)+m_{32}\left(Y-Y_{0}\right)+m_{33}\left(Z-Z_{0}\right)}
\end{aligned}
$$

を書くと容易に理解できよう。ここで

$$
\begin{aligned}
& x_{p}, y_{p} \quad \text {; 主点の写真座標 } \\
& \text { C ; 画面距離 } \\
& X_{o}, Y_{o}, Z_{o} \text {; 投影中心の対象空間座標 } \\
& M=\left(m_{i j}\right) \quad \text {; 回転行列 } \\
& M=\left[\begin{array}{ccc}
1 & 0 & 0 \\
0 & \cos \omega & -\sin \omega \\
0 & \sin \omega & \cos \omega
\end{array}\right]\left[\begin{array}{ccc}
\cos \varphi & 0 & \sin \varphi \\
0 & 1 & 0 \\
-\sin \varphi & 0 & \cos \varphi
\end{array}\right] \\
& {\left[\begin{array}{ccc}
\cos k & -\sin k & 0 \\
\sin k & \cos k & 0 \\
0 & 0 & 1
\end{array}\right]}
\end{aligned}
$$

$\omega, \varphi, k$ はカメラ軸の回転角

式(3)を式(2)の形に書けば次のようになる。

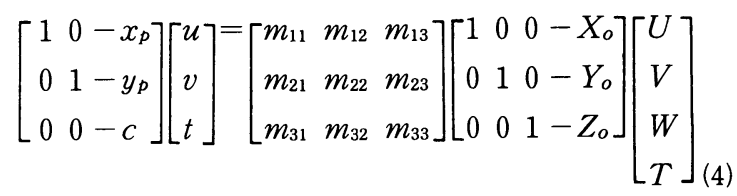

式(4)のパラメータと式(2)の変換係数とは次の関係があ 
る。

$$
\begin{aligned}
& L=\left[\begin{array}{llll}
L_{1} & L_{2} & L_{3} & L_{4} \\
L_{5} & L_{6} & L_{7} & L_{8} \\
L_{9} & L_{10} & L_{11} & 1
\end{array}\right] \\
& =\frac{1}{\lambda}\left[\begin{array}{ccc}
c & 0 & -x_{p} \\
0 & c & -y_{p} \\
0 & 0 & -1
\end{array}\right]\left[\begin{array}{lll}
m_{11} & m_{12} & m_{13} \\
m_{21} & m_{22} & m_{23} \\
m_{31} & m_{32} & m_{33}
\end{array}\right]\left[\begin{array}{llll}
1 & 0 & 0 & -X_{o} \\
0 & 1 & 0 & -Y_{o} \\
0 & 0 & 1 & -Z_{o}
\end{array}\right] \\
& =\frac{1}{\lambda}\left[\begin{array}{lll}
c m_{11}-x_{p} m_{31} & c m_{12}-x_{p} m_{32} & c m_{13}-x_{p} m_{33} \\
c m_{21}-y_{p} m_{31} & c m_{22}-y_{p} m_{32} & c m_{23}-y_{p} m_{33} \\
-m_{31} & -m_{32} & -m_{33}
\end{array}\right]\left[\begin{array}{c}
\alpha \\
\beta \\
\lambda
\end{array}\right]
\end{aligned}
$$

$$
\begin{aligned}
\alpha= & \left(x_{p} m_{31}-c m_{11}\right) X_{o}+\left(x_{p} m_{32}-c m_{12}\right) Y_{o} \\
& +\left(x_{p} m_{33}-c m_{13}\right) Z_{o} \\
\beta= & \left(y_{p} m_{31}-c m_{21}\right) X_{o}+\left(y_{p} m_{32}-c m_{22}\right) Y_{o} \\
& +\left(y_{p} m_{33}-c m_{23}\right) Z_{o} \\
\lambda= & m_{31} X_{o}+m_{32} Y_{o}+m_{33} Z_{o}
\end{aligned}
$$

11ケの $L_{j}$ は 9 個の未知パラメー夕と相互関係がある。 L からこれらを消去すれば次の 2 つの制約式を得る (付録参照)。

$$
\begin{aligned}
g_{1}= & \left(L_{1}^{2}+L_{2}^{2}+L_{3}^{2}\right)-\left(L_{5}^{2}+L_{6}^{2}+L_{7}^{2}\right) \\
& +\left[\left(L_{5} L_{9}+L_{6} L_{10}+L_{7} L_{11}\right)^{2}\right. \\
& \left.-\left(L_{1} L_{9}+L_{2} L_{10}+L_{3} L_{11}\right)^{2}\right] \\
& \cdot\left(L_{9}^{2}+L_{10}^{2}+L_{11}^{2}\right)^{-1}=0 \\
g_{2}= & \left(L_{1} L_{5}+L_{2} L_{6}+L_{3} L_{7}\right)-\left(L_{9}^{2}+L_{10}^{2}+L_{11}^{2}\right)^{-1} \\
& \cdot\left(L_{1} L_{9}+L_{2} L_{10}+L_{3} L_{11}\right) \\
& \cdot\left(L_{5} L_{9}+L_{6} L_{10}+L_{7} L_{11}\right)=0
\end{aligned}
$$

$L_{j}$ の厳密解を求めるときには式(6)の条件を同時に満 たすよう $L_{j}$ を決定しなければならない。もしカメラが 完全カメラでない場合はどうなるだろうか。次の $3 つ$ の場合を調べてみよう。

(1) 測定用カメラ——測定用カメラは完全カメラの 内部標定要素がわかっているものである。レンズ歪が あってもそれらは既知の式で補正される。この場合式 (5)の 3 つのパラメー夕 $x_{p}, y_{p}, c$ に関する条件式が生じ 式(6)に付加される。それらは，付録を参照して，

$$
\begin{aligned}
& x_{p}=\left(L_{1} L_{9}+L_{2} L_{10}+L_{3} L_{11}\right)\left(L_{9}^{2}+L_{10}^{2}+L_{11}^{2}\right)^{-1} \\
& y_{p}=\left(L_{5} L_{9}+L_{6} L_{10}+L_{7} L_{11}\right)\left(L_{9}^{2}+L_{10}^{2}+L_{11}^{2}\right)^{-1} \\
& c^{2}=\left(L_{1}^{2}+L_{2}^{2}+L_{3}^{2}\right)\left(L_{9}^{2}+L_{10}^{2}+L_{11}^{2}\right)^{-1}-x_{p}^{2}
\end{aligned}
$$

ここで， $x_{p}, y_{p}, c$ は既知である。制約条件のついた最 小 2 乗問題については第 4 節で解説する。

(2) 線型のフィルム歪,レンズ歪が入る場合一フィ ルムを拡大複写して観測すると新たな射影歪が加わ る。また極端な収束撮影や偏角撮影をしたときには像

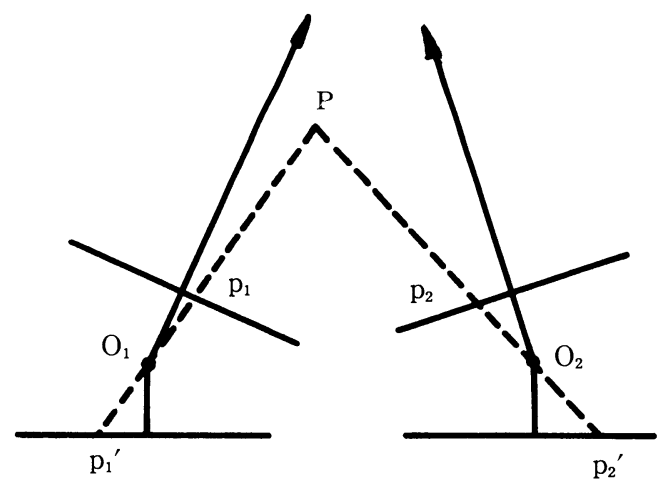

\section{图一 1 収束撮影写真の再投影}

を立体視することができないが，これを図一1のよう に撮影基線に平行な平面に再投影してやれば立体視が できる。しかしキャリブレーションしていないカメラ では投影中心の座標がわからないから, 適当な近似で 再投影せざるを得ない。このとき再度未知の射影変換 を受ける。写真座標系が直交していなかったり伸縮が あれば，像にアフィン歪が加わってくる。これらの場 合, 式(4)は次の様に $u v t$ 座標系から $u^{\prime} v^{\prime} t^{\prime}$ 座標系へ変 換される。

$$
\left[\begin{array}{l}
u^{\prime} \\
v^{\prime} \\
t^{\prime}
\end{array}\right]=\left[\begin{array}{lll}
a_{11} & a_{12} & a_{13} \\
a_{21} & a_{22} & a_{23} \\
a_{31} & a_{32} & 1
\end{array}\right]\left[\begin{array}{l}
u \\
v \\
t
\end{array}\right]=A\left[\begin{array}{l}
u \\
v \\
t
\end{array}\right]
$$

とくにアフィン歪のみが含まれている場合には $a_{31}=$ $a_{32}=0$ である。これは

$$
x^{\prime}=\frac{u^{\prime}}{t^{\prime}}, \quad y^{\prime}=\frac{v^{\prime}}{t^{\prime}} ; x=\frac{u}{t}, \quad y=\frac{v}{t}
$$

とおいてやれば上式は

$$
\left[\begin{array}{l}
x^{\prime} \\
y^{\prime}
\end{array}\right]=\left[\begin{array}{ll}
a_{11} & a_{12} \\
a_{21} & a_{22}
\end{array}\right]\left[\begin{array}{l}
x \\
y
\end{array}\right]^{+}\left[\begin{array}{l}
a_{13} \\
a_{23}
\end{array}\right]
$$

となることからわかる。 $u v t$ 座標系から $u^{\prime} v^{\prime} t^{\prime}$ 座標へ の変換により式(5)は次の様になる。

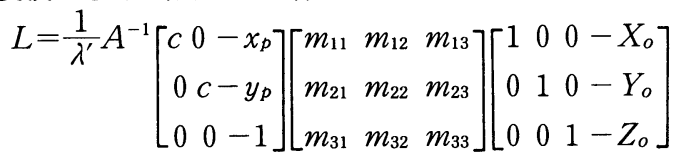

ここで $A^{-1}=\left(\tilde{a}_{i j}\right)$ は $A$ の逆行列,

$$
\lambda^{\prime}=\tilde{a}_{31} \alpha+\tilde{a}_{32} \beta+\tilde{a}_{33} \lambda
$$

である。 $L_{j}$ は 17 ケの未知パラメー夕を含みすべて独立 になる。

（3）非線型のフィルム歪,レンズ歪が入る場合 - - 般にアマチュアカメラでは線型歪だけでなく非線型の 
歪を考えねばならず，補正項を式(1)の右辺に付与して その係数を含めて解くことが行われる。

(2)，(3)は第 3 節で述べる DLT 法を適用すれば良い。

\section{3. 直接線型変換 (DLT) 法}

\section{1 基本式}

Abdel-Aziz，KararaによるDLT 法では非測定用 カメラのキャリブレーションに次式を用いる。

$$
\begin{aligned}
x & +\left(x-x_{p}\right)\left(K_{1} r^{2}+K_{2} r^{4}+K_{3} r^{6}+\cdots\right) \\
& +\left(r^{2}+2\left[x-x_{p}\right]^{2}\right) P_{1}+2\left(y-y_{p}\right)\left(x-x_{p}\right) P_{2} \\
= & \frac{L_{1} X+L_{2} Y+L_{3} Z+L_{4}}{L_{9} X+L_{10} Y+L_{11} Z+1} \\
y+ & \left(y-y_{p}\right)\left(K_{1} r^{2}+K_{2} r^{4}+K_{3} r^{6}+\cdots\right) \\
& +2\left(x-x_{p}\right)\left(y-y_{p}\right) P_{1}+\left(r^{2}+2\left[y-y_{p}\right]^{2}\right) P_{2} \\
= & \frac{L_{5} X+L_{6} Y+L_{7} Z+L_{8}}{L_{9} X+L_{10} Y+L_{11} Z+1}
\end{aligned}
$$

ここで $x, y ;$ 写真座標の測定值

$x_{p}, y_{p} ;$ 写真主点の座標

$r^{2}=\left(x-x_{p}\right)^{2}+\left(y-y_{p}\right)^{2}$

$K_{1}, K_{2}, \cdots \cdots, P_{1}, P_{2}$; レンズ歪の係数

$X, Y$; 対象空間座標

$L_{1} \sim L_{11}$; 未知の変換係数

非測定用カメラではレンズ歪が大きいので，未知の写 真主点の位置を中心とする放射方向と接線方向それぞ れの補正項をつけている。フィルム歪もこれらに吸収 されるとする。しかし実際には補正項としては， $K_{1}$ の みで充分であって式(7)のかわりに，

$$
\begin{gathered}
x+x^{\prime} K_{1} r^{2}=\frac{L_{1} X+L_{2} Y+L_{3} Z+L_{4}}{L_{9} X+L_{10} Y+L_{11} Z+1} \\
\left(x^{\prime}=x-x_{p}\right) \\
y+y^{\prime} K_{1} r^{2}=\frac{L_{5} X+L_{6} Y+L_{7} Z+L_{8}}{L_{9} X+L_{10} Y+L_{11} Z+1} \\
\left(y^{\prime}=y-y_{p}\right)
\end{gathered}
$$

で充分であるとされている1)*。以後の説明には式(8)を 使う。式(8)の未知係数は对象空間内の 6 点以上の基準 点によって最小 2 乗法で求める。ただし基準点は 3 次 元的に配置しておかねばならず，基準点の配置の状態 によってキャリブレーションの精度が大きく変わる。

\section{2 末知係数の決定}

厳密には式(8)の $x, y$ に誤差があるとみなして観測方
程式を立てねばならない。方程式は非線型であるから， 未知量の近似值のまわりに線型化し，〈り返し解法で 未知量を決定する必要がある。しかしこのくり返し最 小 2 乗法はもっと簡単な手続きで以下のように近似的 に解ける。式(8)自身が近似式であるとみなせるので, 最小 2 乗解のみを峳密に求めても意味が薄いから近似 解法は妥当であろう。

（1）直接解法一一式(8)の分母を払い,

$$
\begin{aligned}
& L_{1} X_{i}+L_{2} Y_{i}+L_{3} Z_{i}+L_{4}-x_{i} X_{i} L_{9}-x_{i} Y_{i} L_{10} \\
& \quad-x_{i} Z_{i} L_{11}-x_{i} K_{1} r_{i}^{2} A-x_{i}=r_{x i} \\
& L_{5} X_{i}+L_{6} Y_{i}+L_{7} Z_{i}+L_{8}-y_{i} X_{i} L_{9}-y_{i} Y_{i} L_{10} \\
& \quad-y_{i} Z_{i} L_{11}-y_{i} K_{1} r_{i}^{2} A-y_{i}=r_{y i}
\end{aligned}
$$

を観測方程式とする。添字 $i(i=1,2, \cdots \mathrm{n})$ は観測 点番号を示す。 $r_{x}, r_{y}$ は観測方程式の残差であり， $x^{\prime}$,

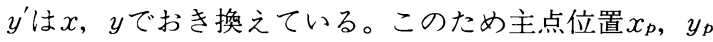
は充分 0 に近くなければならない。通常は像のフレー ムの四隅を仮の指標として $x_{p}, y_{p}$ を決定する。また $A$ は

$$
A=L_{9} X+L_{10} Y+L_{11} Z+1
$$

である。

式(9)では補正項の影響は小さいと考之， $A$ を定数にお いている。 $K_{1} A$ を更めて $K_{1}^{\prime}$ とし，12個の未知数

$$
\left(L_{1}, L_{2}, \cdots, L_{11}, K_{1}^{\prime}\right)
$$

を 6 個以上の基準点から $\Sigma\left(r_{x i}^{2}+r_{y_{i}}^{2}\right) \rightarrow \min$ によっ て求める。式(9)は線型であるから 1 回の計算で終了す る。

（2）〈り返し解法——写真座標の観測值 $x, y$ の誤差 を $v_{x}, v_{y}$ とし, 式(8)を次の観測方程式の形に書く。

$$
v_{x i}-\frac{X_{i}}{A_{i}} L_{1}-\frac{Y_{i}}{A_{i}} L_{2}-\frac{Z_{i}}{A_{i}} L_{3}-\frac{1}{A_{i}} L_{4}+\frac{x_{i} X_{i}}{A_{i}} L_{9}
$$

* しかし恐らくは, カメラ, フィルムの性能, 基準点の 配置によってこれは異ってくるだろう。アマチュアカメラ ではフィルム歪がレンズ歪と同じオーダで発生し，かつ不 規則であるから，実は式(7)の定式化もあやしい。この場合 補正項を直交多項式で与えるとか，レンズ歪を放射方向の みとし，フィルム歪の項を通常の多項式で与えることなど の方法が考えられる5)。しかし場合によっては係数間の相 関が高くなって解が求められなくなることもあり，この場 合線型項のみの係数 $L_{1} \sim L_{11}$ を一旦決定し，その残差を更 めて観測量として補正項の係数を決定することになる5)。 著者としては，レンズ歪，フィルム歪をレゾーで補正でき るか，圧着機構によってフィルム歪を抑える程度の比較的 良いカメラを使い，式(8)によるのが最も実用的ではないか と考える。 


$$
\begin{gathered}
+\frac{x_{i} Y_{i}}{A_{i}} L_{10}+\frac{x_{i} Z_{i}}{A_{i}} L_{11}+x_{i} r_{i}^{2} K_{1}+\frac{x_{i}}{A_{i}}=0 \\
v_{y i}-\frac{X_{i}}{A_{i}} L_{5}-\frac{Y_{i}}{A_{i}} L_{6}-\frac{Z_{i}}{A_{i}} L_{7}+\frac{1}{A_{i}} L_{8}+\frac{y_{i} X_{i}}{A_{i}} L_{9} \\
+\frac{y_{i} Y_{i}}{A_{i}} L_{10}+\frac{y_{i} Z_{i}}{A_{i}} L_{11}+y_{i} r_{i}^{2} K_{1}+\frac{y_{i}}{A_{i}}=0
\end{gathered}
$$

ここで $A_{i}=L_{9} X_{i}+L_{10} Y_{i}+L_{11} Z_{i}+1$

式(10)では $v_{x} K_{1} r^{2}, v_{y} K_{1} r^{2}$ の項を省略している。また式 (10)は非線型であるから，くり返しの最小 2 乗法で未知 係数を求めねばならない。そのためまず次式を連立し て解いて $L_{1} \sim L_{11}$ の初期近似值を求好。 $K_{1}$ の初期值 は 0 とする。

$$
\begin{aligned}
& X_{i} L_{1}+Y_{i} L_{2}+Z_{i} L_{3}+L_{4}-x_{i} X_{i} L_{9} \\
& \quad-x_{i} Y_{i} L_{10}-x_{i} Z_{i} L_{11}=x_{i} \quad(i=1,2, \cdots, 6) \\
& X_{i} L_{5}+Y_{i} L_{6}+Z_{i} L_{7}+L_{8}-y_{i} X_{i} L_{9} \\
& \quad-y_{i} Y_{i} L_{10}-y_{i} Z_{i} L_{11}=y_{i} \quad(i=1,2, \cdots, 5)
\end{aligned}
$$

正規方程式を作るためには，式(10)を近似值のまわりに 展開して線型化してもよいが次のようにするのが簡単 である。最初 $L_{9}, L_{10}, L_{11}$ の近似值を用いて $A_{i}$ の近似 值を計算し，式(10)を線型の観測方程式として正規方程 式を立てる。次にこれを解いてより正確な $L_{1} \sim L_{11}, K_{1}$ を求める。以降は同様のくり返し計算により, 近似值 を更新していく。

\section{3 対象空間座標の決定}

変換係数 $\mathrm{L}_{i}, \mathrm{~K}_{1}$ (あるいは $\left.\mathrm{K}^{\prime}\right)$ が求まれば，これを 使って対象空間の座標を求める測定作業になる。対象 空間が平面であれば単写真測定ができるが，3 次元空 間であれば視点の異った 2 枚以上の写真が必要であ る。これには厳密解法と近似解法が考えられるが, DLT 法では変換係数を近似的に求めているので近似 解法の方が適しており，かつまた解析図化機でリアル タイムに計測していくには，近似解法の方が高速であ り好ましい。厳密な解法については4.3で簡単に触れ る。

変換係数は全て無相関の定数とみなし式(8)の分母を 払い次の観測方程式を立てる。

$$
\begin{aligned}
& \left(\widetilde{x}_{i, n} L_{9}^{n}-L_{1}^{n}\right) X_{i}+\left(\widetilde{x}_{i, n} L_{10}^{n}-L_{2}^{n}\right) Y_{i} \\
& \quad+\left(\widetilde{x}_{i, n} L_{11}^{n}-L_{3}^{n}\right) Z_{i}+\widetilde{x}_{i, n}-L_{4}^{n}=r_{x, n, i} \\
& \left(\tilde{y}_{i, n} L_{9}^{n}-L_{5}^{n}\right) X_{i}+\left(\tilde{y}_{i, n} L_{10}^{n}-L_{6}^{n}\right) Y_{i} \\
& \quad+\left(\tilde{y}_{i, n} L_{11}^{n}-L_{7}^{n}\right) Z_{i}+\tilde{y}_{i, n}-L_{8}^{n}=r_{y, n, i}
\end{aligned}
$$

ここで $L_{j}^{n}(i=1,2, \cdots, 11): n$ 番目の写真の 11 ケ の変換係数 $\tilde{x}_{i, n}, \widetilde{y}_{i, n}:$ 点 $P_{i}$ の $n$ 番目の写真座標, 位置補正 を次式で行った後の座標

$$
\tilde{x}=x+K_{1} x r^{2}, \quad \tilde{y}=y+K_{1} y r^{2} \quad \text { （添字略） }
$$

$X_{i}, Y_{i}, Z_{i}$ : 点 $P_{i}$ の対象空間座標

3 枚以上の写真に対象が写っているときには, 各写 真ごとに座標計測を行って最小 2 乗法で $X_{i}, Y_{i}, Z_{i}$ を 求める。

2 枚の写真で立体観測ができれば連続的に対象の表 面を追跡できる。このとき観測行列は 4 行 3 列であり， 各点ごとに正規方程式を解いても，たとえば Gau $\beta$ Seidel 法などのくり返し法によれば，1つ前の測定值 から近似值が与えられるから, 収束は速く実用的な追 随速度が得られるだろう。もし計算機の能力が不足す るようであれば，次の様にしてもほとんど変わらない 值が得られるだろう。式(12)の右辺を 0 とおき 2 式から $Y_{i}$ を消去した式を作り, 左右の写真座標から $X_{i}, Z_{i}$ を 連立して解く。 $Y_{i}$ はそれぞれの写真に対して $X_{i}, Z_{i}$ の 值から計算した值を平均して求める。

キャリブレーションが完全であれば 2 枚の写真上の 1 組の対応点の $x y$ 座標 $\left(x_{i, 1}, y_{i, 1}\right),\left(x_{i, 2}, y_{i, 2}\right)$ のうち 3 つのみが独立であり, 他の 1 つは対象空間座標の決 定に不要であるが, 実際には残存誤差があるため上記 のように $(4 \times 3)$ 観測式を立てて最小 2 乗法で対象 空間座標を決定するのである。

\section{4. 完全カメラ, 測定用カメラのキャリブ レーション}

\section{1 制約条件式がついた場合の変換係数の決定}

この節では式(6)の制約条件式のついた場合に式(1)の 11 ケの変換係数 $\mathrm{L}_{j}$ を求める方法について述べる。独立 した係数は 9 個であるから基準点は 5 個以上あれば良 い。ただしこれらは 3 次元的な配置が必要である。式 (1)を観測方程式に書き直すと次式を得る。

$$
\begin{aligned}
& x_{i}+v_{x i}=\frac{L_{1} X_{i}+L_{2} Y_{i}+L_{3} Z_{i}+L_{4}}{L_{9} X_{i}+L_{10} Y_{i}+L_{11} Z_{i}+1} \\
& y_{i}+v_{y_{i}}=\frac{L_{5} X_{i}+L_{6} Y_{i}+L_{7} Z_{i}+L_{8}}{L_{9} X_{i}+L_{10} Y_{i}+L_{11} Z_{i}+1}
\end{aligned}
$$

添字 $i$ は点 $\mathrm{P}_{i}$ に関する諸量, $v_{x i}, v_{y i}$ は写真座標の誤差 である。制約条件のついた最小 2 乗の解法としてはラ グランジェ乗法を使う方法が一般的であるが, 制約条 件式を重み無限大（あるいは分散 0 ）の観測方程式と して観測式の系の一部を占めるように組み込んでしま 
う方が簡単になる。以下に両者を説明する。

(1) ラグランジェの未定係数を用いる方法——式(13) を $\mathrm{L}_{1} \sim \mathrm{L}_{11}$ の近似值のまわりに展開して線型化する (あるいは式(9)のように分母を払ってしまっても解け るが最小 2 乗法の厳密な意味はなくなる)。同じく式(6) を線型化し，以下の 2 つの系を得る。

$$
\begin{aligned}
& \boldsymbol{v}_{1}=A_{1} \boldsymbol{u}-\boldsymbol{l} ; \text { 重み行列 } P_{1} \text { （通常単位行列） } \\
& \mathbf{0}=A_{2} \boldsymbol{u}-\boldsymbol{d}
\end{aligned}
$$

ここで,

$$
\boldsymbol{v}_{1}^{T}=\left(v_{x 1}, v_{y 1}, v_{x 2}, y_{y 2}, \cdots, v_{x n}, v_{y n}\right): \text { 写真座 }
$$

標の誤差ベクトル

$$
\boldsymbol{u}(11 \times 1) \text { : 未知係数 } L_{j} \text { の補正量ベクトル }
$$$$
A_{1}(11 \times 2 n), A_{2}(11 \times 2): \text { 係数行列 }
$$

$\boldsymbol{l}(2 n \times 1), \boldsymbol{d}(2 \times 1):$ 定数項べクトル

$L_{j}$ の最確值はグランジェ乗数べクトル $\lambda^{T}=\left(\lambda_{1}, \lambda_{2}\right)$ を 使って

$$
\begin{aligned}
\phi(\boldsymbol{u})= & \frac{1}{2}\left(A_{1} \boldsymbol{u}-\boldsymbol{l}\right)^{T} P_{1}\left(A_{1} \boldsymbol{u}-\boldsymbol{l}\right) \\
& -2 \lambda^{T}\left(A_{2} \boldsymbol{u}-\boldsymbol{d}\right) \rightarrow \min
\end{aligned}
$$

より求められる。実際にこれを解いてみると

$$
\begin{aligned}
\frac{1}{2} \frac{\partial \phi}{\partial \boldsymbol{u}} & =\left(A_{1}^{T} P_{1} A\right) \boldsymbol{u}-A_{1}^{T} P_{1} \boldsymbol{l}-A_{2}^{T} \lambda=0 \\
\boldsymbol{u} & =\left(A_{1}^{T} P_{1} A_{1}\right)^{-1}\left(A_{1}^{T} P_{1} \boldsymbol{l}+A_{2}^{T} \lambda\right)
\end{aligned}
$$

条件式（式(14)の第 2 式）に式(15)を代入して $\lambda$ について 解くと

$$
\begin{aligned}
\lambda= & \left(A_{2}\left(A_{1}^{\mathrm{T}} P_{1} A_{1}\right)^{-1} A_{2}^{T}\right)^{-1} \\
& \left\{\boldsymbol{d}-A_{2}\left(A_{1}^{\mathrm{T}} P_{1} A_{1}\right)^{-1} A_{1}^{T} P_{1} \boldsymbol{l}\right\}
\end{aligned}
$$

式(15), (16)が解である。こうして得た $L_{i}$ の補正量 $\boldsymbol{u}$ からよ ク良い近似を求め, 上記の演算を $\boldsymbol{u}$ が充分 0 に収束す るまでくり返す。

（2）重み無限大の観測式と見なす方法一一制約条件式 (6)を観測式(13) と共に線型化し，次の観測方程式を作る。

$$
\boldsymbol{v}=\left[\begin{array}{l}
\boldsymbol{v}_{1} \\
\boldsymbol{v}_{2}
\end{array}\right]=\left[\begin{array}{l}
A_{1} \\
A_{2}
\end{array}\right]^{\boldsymbol{u}-}\left[\begin{array}{l}
\boldsymbol{l} \\
\boldsymbol{d}
\end{array}\right] \text {; 重み行列 } P=\left[\begin{array}{cc}
P_{1} & 0 \\
0 & a E
\end{array}\right]_{(17)}
$$

ここで $E(2 \times 2)$ は単位行列, $a$ は非常に大きい実数 である。極端に大きな数字を与えると $P$ は計算機のま るめ誤差による桁落ちで特異行列になってしまうので 解けない。たとえば $P_{1}=E(2 n \times 2 n)$ のとき $a=1.0 \times$ $10^{2} \sim 1.0 \times 10^{3}$ 程度とする。解は

$$
\boldsymbol{u}=\left(A^{T} P A\right)^{-1} A^{T} P \boldsymbol{l}
$$

である。もちろん $a$ が有限值であるからこれは近似解 であるが実用上充分である。この場合も $\boldsymbol{u}$ が充分 0 に 収束するまで計算をくり返す。

\section{2 変換係数からの内部, 外部の標定要素の決定}

通常必要はないが内部外部の標定要素を変換係数 L から決定することができる。内部標定要素はすでに 式(6)に与えた。

まず撮影点 (投影中心) の座標 $\left(X_{0}, Y_{0}, Z_{0}\right)$ は式 (2)より, 対応する写真座標が不定になることから,

$$
\begin{aligned}
& L_{1} X_{0}+L_{2} Y_{0}+L_{3} Z_{0}+L_{4}=0 \\
& L_{5} X_{0}+L_{6} Y_{0}+L_{7} Z_{0}+L_{8}=0 \\
& L_{9} X_{0}+L_{10} Y_{0}+L_{11} Z_{0}+1=0
\end{aligned}
$$

を連立に解けば得られる。回転行列 $\left(m_{i j}\right)$ は式(5)より

$$
\begin{array}{ll}
m_{31}=-\lambda L_{9}, & m_{32}=-\lambda L_{10}, \quad m_{33}=-\lambda L_{11} \\
m_{11}=\left(\lambda L_{1}+x_{p} m_{33}\right) / c, & m_{21}=\left(\lambda L_{5}+y_{p} m_{31}\right) / c \\
m_{12}=\left(\lambda L_{2}+x_{p} m_{32}\right) / c, & m_{22}=\left(\lambda L_{6}+y_{p} m_{32}\right) / c \\
m_{13}=\left(\lambda L_{3}+x_{p} m_{33}\right) / c, & m_{23}=\left(\lambda L_{7}+y_{p} m_{33}\right) / c
\end{array}
$$

より得られる。

\section{3 対象空間座標の決定（厳密解法）}

変換係数 $L_{j}$ が確定すると 2 組以上の写真座標から 对象空間座標が決定される。その方法はすでに $3.3 て ゙$ 述 べた近似解法によればいいが, 完全カメラ, 測定用カ メラでは誤差は写真座標のみに入ると考えられるので 次の観測方程式を立てる方が望ましい。

$$
\begin{gathered}
x_{i, n}+v_{x i, n}=\frac{L_{1}^{n} X_{i}+L_{2}^{n} Y_{i}+L_{3}^{n} Z_{i}+L_{4}^{n}}{L_{9}^{n} X_{i}+L_{10}^{n} Y_{i}+L_{11}^{n} Z_{i}+1} \\
y_{i, n}+v_{y i, n}=\frac{L_{5}^{n} X_{i}+L_{6}^{n} Y_{i}+L_{7}^{n} Z_{i}+L_{8}^{n}}{L_{9}^{n} X_{i}+L_{10}^{n} Y_{i}+L_{11}^{n} Z_{i}+1}
\end{gathered}
$$

記号は式(12)と共通であるが写真座標の補正項は入れて ない。式(21)は非線型であるから $X_{i}, Y_{i}, Z_{i}$ の近似值の まわりに展開して線型化しなければならない。最初の 近似值は式(12)を 2 枚の写真点の 2 つの $x$ と 1 つの $y$ について立てて連立方程式を解いて得られる。

付録 制約条件式(6), (6)'の導出

$$
\text { 一般に直行行列 } M=\left(m_{i j}\right) \text { は }
$$

$$
M M^{\mathrm{T}}=E \quad \text { (単位行列) }
$$

の性質を持つので，これを成分表示すると

$$
\left[\begin{array}{lll}
m_{11} & m_{12} & m_{13} \\
m_{21} & m_{22} & m_{23} \\
m_{31} & m_{32} & m_{33}
\end{array}\right]\left[\begin{array}{lll}
m_{11} & m_{21} & m_{31} \\
m_{12} & m_{22} & m_{32} \\
m_{13} & m_{23} & m_{33}
\end{array}\right]=\left[\begin{array}{lll}
1 & 0 & 0 \\
0 & 1 & 0 \\
0 & 0 & 1
\end{array}\right]
$$

すなわち

$$
\begin{aligned}
& m_{11}^{2}+m_{12}^{2}+m_{13}^{2}=1 \\
& m_{21}^{2}+m_{22}^{2}+m_{23}^{2}=1
\end{aligned}
$$




$$
\begin{aligned}
& m_{31}^{2}+m_{32}^{2}+m_{33}^{2}=1 \\
& m_{11} m_{21}+m_{12} m_{22}+m_{13} m_{23}=0 \\
& m_{11} m_{31}+m_{12} m_{32}+m_{13} m_{33}=0 \\
& m_{21} m_{31}+m_{22} m_{32}+m_{23} m_{33}=0
\end{aligned}
$$

式(5)より

$$
\begin{aligned}
\cdot L_{9}^{2}+L_{10}^{2}+L_{11}^{2}= & \left(m_{31}^{2}+m_{32}^{2}+m_{33}^{2}\right) \lambda^{-2}=\lambda^{-2} \\
\cdot L_{1}^{2}+L_{2}^{2}+L_{3}^{2}= & \left\{c^{2}\left(m_{11}^{2}+m_{12}^{2}+m_{13}^{2}\right)\right. \\
+x_{p}^{2}\left(m_{31}^{2}+\right. & \left.m_{32}^{2}+m_{33}^{2}\right) \\
-2 c x_{p}\left(m_{11}\right. & \left.\left.m_{31}+m_{12} m_{32}+m_{13} m_{33}\right)\right\} \lambda^{-2} \\
= & \left(c^{2}+x_{p}^{2}\right) \lambda^{-2} \\
\cdot L_{5}^{2}+L_{6}^{2}+L_{7}^{2}= & \left\{c^{2}\left(m_{21}^{2}+m_{22}^{2}+m_{23}^{2}\right)\right. \\
& +x_{p}^{2}\left(m_{31}^{2}+m_{32}^{2}+m_{33}^{2}\right) \\
& -2 c y_{p}\left(m_{21} m_{31}+m_{22} m_{32}\right. \\
& \left.\left.+m_{23} m_{33}\right)\right\} \lambda^{-2} \\
= & \left(c^{2}+y_{p}^{2}\right) \lambda^{-2}
\end{aligned}
$$

以下同様の計算で

- $L_{1} L_{5}+L_{2} L_{6}+L_{3} L_{7}=x_{p} y_{p} \lambda^{-2}$

- $L_{1} L_{9}+L_{2} L_{10}+L_{3} L_{11}=x_{p} \lambda^{-2}$

$$
\text { - } L_{5} L_{9}+L_{6} L_{10}+L_{7} L_{11}=y_{p} \lambda^{-2}
$$

以上の 6 式から $x_{p}, y_{p}, c, \lambda$ を済去すれば式(6)を得る。 式(6)も $x_{p}, y_{p}, c$ を $L_{j}$ で表わすことによって得られる。

1) Hand book of Nontopographic Photogrammetry: ASP 編, 1979, pp. 35-38

2 ) Abdel-Aziz, Y. I. and Karara, H. M. : Direct Linear Transformation from Comparator Coordinates into Object Space Coordinates in Close-Range Photogram metry, University of Illinois at Urbana-Champaign, Urbana, Illinois, January 26-29, 1971, pp. 1-18

3 ) Bopp, H and H. Krauss: An Orientation and Calibration Method for Non-Topographic Applications, PE \& RS, Vol. 44,No. 9, 1978, pp. 1191-1196

4) Wong, K. W.: Mathematical Formulation and Digital Analysis in Close-Range Photogrammetry, PE \& RS, Vol. 41, No. 11, 1975, pp. 1355-1373

5 ) 村井俊治, 松岡龍治, 奥田 勉：セルフキャリブレー ション付きバンドル法の精度比較, 写真測量とりモート センシング, Vol.23, No.2, 1984, pp.4-11 